\title{
Jonah, the Missionary Who Said “No”
}

\author{
Elia Shabani Mligo \\ University of Iringa, Tanzania
}

\begin{abstract}
What is the mission of the African church in the 21st century? How can the African church carry out this mission work? Is it possible for the poor and marginalized African societies to do mission to the rich and economically powerful nations of the North? Through the reading of the book of Jonah, this article claims that globalization and its challenges provide the African church with a new context to carry out mission work. It further argues that the African church has not yet fulfilled God's divine mandate to send the message of salvation to people of various contexts within this globalized world. In this case, the book of Jonah is an analogy of the way God's mandate to do mission to great powers of this world, which has received great resistances from the African marginalized peoples.
\end{abstract}

Keywords: mission, the African church, globalization

\section{Introduction}

Any titled "Christian Mission" derives its roots from the Christian Holy Scriptures. They alone are the ones with authority to make a human being "wise unto salvation". From them, the human being derives the message, the mandate, the motivation, and the methodology to serve God. Without the Word of God (Holy Scriptures), any Christian missionary movement becomes devoid of meaning and validity (Jesse N. K. Mugambi, 1989). Moreover, it is from the Christian Holy Scriptures where the missionary derives the message to carry with him/her; the message of God's merciful love for the world is based upon God's sovereignty and divine wills. This indicates that God is the Creator, Sustainer, and Ruler of the universe. God is the destiny of humankind and of the message for the missionary activity. In this case, as the contextual missiologist Jooseop Keum (2011) clearly puts it: "Mission is participating in God's plan and work to save the whole oikoumene. We are called as co-workers for this glorious task as the people of God and the disciples of Jesus Christ” (p. 125).

However, people's call is based on God's Divine sovereignty. The divine sovereignty of God is, in its totality, incomprehensible (Donald Senior \& Carroll Stuhlnueller, 1983). God is almighty powerful. God is perfectly wise with an intrinsic goodness. These are what we may call "the triadic" components of the sovereignty of God. To say "I believe in God the Father Almighty...)" (as people always state in the first Article of the Apostles' Creed) is probably not enough to portray the sovereignty of God. This is because, if God becomes all powerful but unwise, God might conceivably use the power foolishly and come out with futile and hurting pursuits. Suppose God were all powerful, but not all good, God might conceivably abuse the power bringing about detrimental effects to the creation. However, God's dealings with the creation are fair and perfect because of the Sovereignty that exceeds every human understanding.

Elia Shabani Mligo, Ph.D, University of Iringa, Amani Center.

Correspondence concerning this article should be addressed to University of Iringa, Amani Centre,P.O.Box 958, Njombe Tanzania..E-mail: eshamm2002@yahoo.co.uk. 
In this article, the writer discusses the sovereignty of God as reflected in the book of Jonah and the missionary mandate of the African church in the 21st century context. The writer's major aim is to respond to the following question: How can the message of Christ be sent to people who are changing now and then, with a culture that is always in flux, with a diverse technological advancement, and with a differently growing mindset? In other words, what stance is proper for an African church to respond to the command "to go" and send the message of Christ to other non-African great peoples (nations) under the postmodern world with its challenges and promises? Or, as the missionary Brian Hearne (1993) states: "Is mission [in the 21st century] about telling people what we know and what we think they ought to know, or is it a kind of mutual admiration society, which challenges nobody?” (p. 91)

A similar question most likely applied to the context of Jonah's missionary obligation: How could Jonah dare to "to go" to Nineveh, the great city with power, a place where people had a different cultural background from his own, people with their own civilization, and most of all a heathen people and out of God's covenant according to Jewish understanding? The above questions call for an investigation about the sovereignty of God and God's mandate for mission work in this postmodern context and its challenges.

Through reading the book of Jonah, the writer focuses the discussion on the African church's mandate for mission in the $21^{\text {st }}$ century as a fulfilment of God's plan for human salvation. This article does not focus on exploring the history of Christian mission, rather on the theological reflection of the book of Jonah to the African church's mandate for mission in the $21^{\text {st }}$ century context. In this case, the article will provide a brief overview of the book of Jonah as a book of prophecy, the distinctive scenes it has, the reflection of its message in the $21^{\text {st }}$ century African church, and the light it sheds to the missionary mandate of the African church in this $21^{\text {st }}$ century context.

\section{Missionary Mandate and the Sovereignty of God: A Brief Reading of the Book of Jonah}

The book of Jonah has been for a long time very significant for the proper understanding of God's mandate to people to do mission, especially among Gentiles (heathens). However, the book has been used to portray how deep is the resistance, this mandate encounters among the people whom God obliges to carry out mission. The book of Jonah is among the 12 books of the Minor Prophets. While other prophets' books consist of the collection of the various prophets' words, Jonah's book is mainly a story about the prophet himself. In any case, this story is written with a specific purpose to the readers. In fact, it is not an historical journal, but a story with a specific message. The meaning and message of the whole episode are not found in the story of the great fish and what it did to Jonah, but in the mercy of God, that God spared Nineveh, the wicked city, making the king and the people to repent when they heard the message through Jonah. De la Torre (2007), states clearly the major question to note as one traverses the chapters of the book: One of "The central themes of Jonah is clearly repentance. But who is called to repent? The Assyrians or Nineveh or both parties?” (p. 59)

\section{Division of the Book of Jonah}

If read carefully, the reader may notice clearly that the book of Jonah is divided into eight distinctive scenes, dramatically presented, each having God's all-embracing plan to bring the message to the Gentiles (to Nineveh), and Jonah's futile personal endeavours to suppress these plans. In reading behind the text, the message of the book is totally directed to Israel who was so preoccupied oneself that she no longer directed her eyes towards other nations. She received election and salvation from God, but she never set any foot to other 
nations to let them know that Yahweh saves, and that Yahweh's judgment is upon Yahweh's own hand and will be executed justly. Here God seems to wrestle against Israel's strict ethnocentrism which endeavours to restrict Yahweh's activities only in the boundaries of Israel.

\section{Yahweh's Command to Jonah}

Now the writer describes the eight scenes of the book of Jonah before discussing its implications to the African church of the $21^{\text {st }}$ century. The first scene opens with Jonah, the son of the prophet Amittai, receiving a command from Yahweh "to go" to Nineveh (the Hebrew word used is lek, in the LXX the word is poreutheti). Nineveh was a very centre of totalitarianism, brutality and war-like attitude (Leslie C. Allen, 1976). Yahweh wants Jonah to warn Nineveh of the judgment upon her and call her to repentance. But Jonah refuses and prepares himself to flee away from the face of Yahweh.

However, in this first scene, an antagonistic interplay is notable: Yahweh insists in the call for Jonah to go to Nineveh while Jonah insists in his rejection to obey Yahweh's demand. Jonah is awakened from deep sleep when the mighty wind blows so that he prays to his God. This is God's initial initiative through the mariner to lead Jonah to repentance and obedience to God's call. Jonah responds to this initiative by a silence. Jonah does not respond to the ship's captain to cry to his God for help. Despite the fact that Jonah's prayer to God could have saved his own life and the lives of those in the ship, yet Jonah knowingly selects death by storm rather than obeying the will of Yahweh (De la Torre, 2007).

\section{Yahweh's Response to Jonah's Disobedience}

In the second scene, Yahweh responds to the flight of Jonah by sending a mighty storm. Once more, lots are casted, Jonah is indicated and the mariners direct all questions to him to know what he had done: "Then they said to him, 'Tell us in whose account this evil has come upon us. What is your occupation? And whence do you come? What is your country? And of what people are you?'” Jonah confesses clearly the deep anger of God whom he was reluctant to obey: "And he said to them, 'I am a Hebrew; and I fear the Lord, the God of heaven, who made the sea and the dry land'”. Jonah, in the midst of the wind blowing over against the ship, announces the mighty deeds of Yahweh, God of the Hebrews. This indicates the initiatives of the heathen mariners to bring him to confession and repentance; once more, Jonah chooses death rather than serving the purpose of Yahweh.

The main question asked by the mariners: "What shall we do to you, that the sea may quiet down for us?" is a typical call for Jonah to repent and obey to Yahweh whom he confessed as being his God. However, Jonah's response indicates his unwillingness to go to Nineveh, and hence obey Yahweh's call: "Take me up and through me into the see; then the sea will quiet down for you; for I know it is because of me that this tempest has come before you'” The question is: What makes Jonah find death to be better than going to Nineveh? What is really at stake in this interaction? Is it Nineveh's view in the eyes of Jonah, or Jonah's will of Yahweh's call to preach the good news? These are open questions that can still push us further towards understanding the text people have.

\section{The Large Fish and Its Significance}

The third scene describes a large fish, which, at Yahweh's instructions, opens its mouth to swallow Jonah. Jonah has now no way to escape Yahweh's missionary mandate to save Nineveh. In the fourth scene, Jonah acknowledges and appeals for the divine mercy in the belly of the fish. He quotes various psalms panting after those promises, which were claimed by worshipers of Yahweh in the Temple. Panting over the psalms Jonah 
offers a magnificent prayer of thanksgiving to Yahweh. Despite the fact that he did not obey the mariners' request to pray to his God, now Jonah is caught in limbo to fulfil what he prior rejected.

However, the prayer of Jonah is not of repentance and willingness to obey Yahweh's command to preach the message of grace to the heathen city of Nineveh, but a prayer that still casts blames upon Yahweh. First, Yahweh is blamed by hurling Jonah into the sea, a thing that was done by the mariners in response to Jonah's own request. Jonah pants: "For thou didst cast me into the deep, into the heat of the seas, and the flood was round about me, all thy waves and thy billows passed over me” Second, Jonah blames Yahweh for casting him away from Yahweh's sight, a thing that is done by Jonah himself in his effort to flee from Yahweh's call. Jonah panted thus: "Then I said, 'I am cast out from thy presence; how shall I again look upon thy holy temple?" (Jonah 2: 4) In this case, up to the end of this scene Jonah never dares to repent of his futile pursuits, but only ends the prayer by acknowledging that salvation comes only from Yahweh (De la Torre, 2007).

\section{The Fish Vomits Jonah and Yahweh Resumes the Command}

In the fifth scene, the fish vomits Jonah on the shores of the sea, he becomes himself already experienced the saving mercy of Yahweh. Through this experience, Jonah becomes himself a testimony that God does not rejoice on the death of the sinner, rather God rejoices on their conversion.Yahweh reassumes the command to Jonah "to go" to Nineveh. At this time, Jonah responds to Yahweh's command. When in Nineveh, Jonah walks in all the streets of the great pagan city and proclaims the proclamation of Yahweh. Jonah, a person from among the Israelites in the margins of society, is obliged to proclaim (qara) that though Nineveh, the large city, has rebelled against Yahweh in such a great extent, she is still the object of Yahweh's fervent concern; and that unless she repents and turns back to Yahweh, she will be destroyed. In this case, Jonah's message to Nineveh becomes of both judgment and gospel, of threat and promise.

\section{Nineveh's Response to the Call of Repentance}

The sixth scene portrays Nineveh's response to the call to repentance proclaimed by Jonah. The proud king steps down from his royal throne and obeys the call to repentance while being followed by many others among his subordinates. The king and his followers fasted and put on sackcloth's, as a sign of renunciation of their devilish acts towards Yahweh. Up to this point, Yahweh's plan has been fulfilled. People in Nineveh have ceased their devilish works and turned away from their idols to serve Yahweh. Hence, because of the faithfulness to the promises, Yahweh repents of the evils that were intended to be inflicted upon people in Nineveh.

However, most surprising, while the pagan king and his followers obey Yahweh through the words proclaimed by the recalcitrant prophet and renounce all their evil deeds, yet Jonah hardly repents of what he had planed to do against Yahweh's plan. What does this tell the African churches of people's current situation?

\section{The Response of Jonah to Yahweh's Mercy upon the Wicked Nineveh}

The seventh scene portrays an amazing event. Jonah becomes furious that Yahweh has extended the mercy beyond the borders of Israel to the Gentiles. Jonah had no conception of Gentiles being part of Yahweh's salvation history. "The Assyrians, in Jonah's mind, are pure evil, undeserving of any compassion or mercy. Because they are monsters, not humans, they deserve retribution, justice that is quick and stiff" (De la Torre, 2007, p. 91). The question arises: Why is Jonah angry while he knew beforehand that he was sent to preach repentance to Nineveh, the Gentile city? Is Jonah's anger something good or bad?

The anger of Jonah has drawn attention among scholars of this book. Barbara Green, for example, 
responds to the above questions thus:

\footnotetext{
“Anger has its positive place as an energy, as an apt reaction to something that is seriously wrong. Anger is often an authentic response we do best to recognize, acknowledge, channel, and transform. But anger can also be destructive, out of control, misbegotten, and wasted. Jonah is angry because he lost something that made him happy-fair cause for his anger” (Barbara Green, 2005, p. 140)
}

Following the above quotation, the possible answer to the question about the anger of Jonah is that Jonah is infuriated by Yahweh's treatment of those outside the covenant in the same way as those within the covenant (Israel). Jonah's prayer in 4: 2 indicates clearly this concern: “And he prayed to the Lord and said, 'I pray thee, Lord, is not this what I said when I was yet in my country? That is why I made haste to flee to Tarshish; for I knew that thou art a gracious God and merciful, slow to anger, and abounding in steadfast love and repentest of evil. Therefore now, O Lord, take my life from me, I beseech thee, for it is better for me to die than to live'”. Yahweh's mercy to the Gentiles makes Jonah angry (Hugh Martin, 1958, pp. 344-345). In other words, Jonah fails to distinguish between covenant and none covenant people in the midst of Yahweh's mercy. Yahweh extends the mercy to Israel's oppressing empire in the same as Yahweh treats the covenant people. In most cases, this is what people may call Jonah's "grave sin”. Jonah's futile endeavours to suppress Yahweh's plans, and his unwillingness to repent of his recalcitrance were done because of his failure to understand Yahweh's covenant purpose - to bring the good news of Yahweh's salvation to the heathen. But his anger because of the saved heathen (Nineveh) hardly has plausible grounds.

\section{Yahweh's Second Attempt to Teach Jonah}

In the eighth scene, Yahweh is still constantly involved in teaching Jonah another lesson. Since Jonah seems to have not understood the previous dealings of Yahweh to himself and to Nineveh, Yahweh tries another approach - the miraculous tree which gives Jonah protection against the beating sun which then withers immediately. Yet, Jonah hardly understands it. The book of Jonah ends up with a complex question: God reached the goal to bring Nineveh to salvation, what about the destiny of the recalcitrant Jonah? The common agreement for the plausible answer to this question is yet future.

\section{The Book of Jonah and the African Church of the $21^{\text {st }}$ Century Context}

It is an undeniable fact that the true and glorious gospel is that God loves the world, that God sent Christ who died for the sins of the whole world, and that whoever calls upon the name of Christ shall be saved. But, here again comes Paul with extremely tangible questions: How are men to call upon him (Christ) in whom they have not believed? How are they to believe in him of whom they have never heard? How shall they hear without a preacher? This logical presentation of questions, which Paul does, demands that the ordination of God's salvation to all mankind shall be fulfilled through the preaching of the gospel.

\section{God Calls and Sends African Churches to Preach the Gospel to All Humanity}

In fact, it is unimaginable that God can make the good news of salvation known to the heathen, powerful and oppressive nations of the globalized world, without the employment of human agents. When some other questions about the destiny of the heathen, powerful and oppressive nations who have never heard the gospel fall upon people today, they may come to the realization that the African church as a New Israel has not yet completed her mandate to let this message be known to every humankind. This means that the compression of the world into a global village and the extension of modernity that they claim to have in this globalized world 
have hardly enabled all people to be fully aware of God's saving mercy (Robert J. Schreiter, 1997).

The message of the book of Jonah is not limited only to the Old Israel with her ethnocentrism, as people just pointed out above; but, it is also addressed to the African church of the $21^{\text {st }}$ century, with her own context, the African church which tries various ways of evading God's command to speak the message of salvation to the globalized world and its current situation. Jonah's evasion endeavours represent a lazy, reckless, and negligent African church that hardly wishes to respond to God's command "to go" into the world, towards the great nations of today that oppress the poor and marginalized nations, and to the multicultural African church of the globalized world to proclaim the message of salvation (T. Watson Street, n.d.).

\section{Jesus Plays a Role Model for African Churches to Follow}

In whatever mission of the African church, Jesus is the role model. The mission of Jesus is clearly stipulated in the Gospel of Luke to bring good news to the poor and to set free all those who are oppressed by the worldly powers. The missiologist Brian Hearne (1993) states aptly about the passion of Jesus towards God's mission:

"The passion of Jesus for God's will to be done, and which led him to an appalling death, is still, and always will be, the standard for all who claim to be his followers. His journeys in "Galilee of the Nations" showed him how non-Jews were also open to the love of God. Jesus saw his mission as being a messenger of and witness to God's saving love for all the people of Israel, but this love reached to the ends of the earth (...). In Jesus people see the universal reality of God's love, a love that excludes nobody” (p. 91).

The African church of the $21^{\text {st }}$ century, as a follower of Jesus, has a universal message to the current effects of globalization; it has the message for economic injustices prevailing in the current world. It has the message for the erosion of cultural values in the world perpetuated by media of communication. It has a message for the place of God in this world where material wealth is more valued by the great powers of this world than anything else. It has a message in the world where the longing for power and control over others has made the world a very bad place to live. As De la Torre clearly (2007) states "Not only are salvation and liberation for the oppressed; they are also for the oppressors" (p. 124). De la Torre (2007) further notes: "God loves all created beings, including oppressors, and wants them to repent and regain their humanity” (p.66). Therefore the African church has an obligation to preach the word of God to all kinds of people, oppressors and none oppressors because God does not rejoice for the oppressor who dies in wickedness.

What has the African church done to fulfil its mandate to portray the sovereignty of God in the midst of all these events, and to the oppressors of the weak? How has the African church of the $21^{\text {st }}$ century responded to the command "to go" to the mighty powers of this world that oppress the weak economically, religiously, culturally, and socially? Has the African church asked herself about her obligation to send the message of God to the millions of people that are in unfortunate situations in various places of the world? In brief, how far has the African church of the $21^{\text {st }}$ carried out a prophetic mission to people of the current context?

\section{The Major Task of the African Churches}

According to the writer's view, the message of the book of Jonah and the eight scenes discussed above are directed towards the $21^{\text {st }}$ century African church that seems to be devoid of what $\mathrm{T}$. Watson Street calls "the readiness of the Church for Christian missions”. It is directed to the African church that stays sedentarily enjoying her hierarchical structures and "bureaucracies, which provide a good self-image and self-esteem" 
(Paulo Isack Akyoo, 1987, p. 88) while leaving millions of people without any knowledge of Gods message in their situation. It is directed towards the African church that has hardly turned back and looked upon her concern to the various situations prevailing in the globalized world. Jonah's "concern was dictated by [his own] self-interest, not by a genuine love” (Allen, 1994, p. 234). As one can note from the story, Jonah's concern was to the tree and the benefits he got from it, but never on the gardener (God) and the obligations he got from God. In this case, one can notice that the egocentrism of Jonah is most likely reflected to the African church of the $21^{\text {st }}$ century that hardly dares to proclaim the prophetic message of Christ to existing powers of this globalized world.

The book of Jonah points out clearly the Mission of Jesus from heaven committed to his church on earth. The African church's mandate for mission is stipulated clearly in the Great Commission, the final words of Jesus:

"All authority in heaven and on earth has been given to me. Therefore, go and make disciples of all nations, baptizing them in the name of the Father and of the Son and of the Holy Spirit and teaching them to obey everything I have commanded you. And surely I am with you always, to the very end of the age".

The task is stated clearly: to make all nations disciples through baptizing and teaching them the truth of the gospel. A similar task was committed to Jonah: to preach and rebuke about the wickedness of Nineveh. The question of context comes in here. The context of Jonah is different from the context of Jesus and his disciples. The context of Jesus and his disciples is also different from that of the church of the fourth and fifth centuries. This means that Jonah speaks about the mission of the church in various contexts of its existence, including the $21^{\text {st }}$ century.

What does it real entail to fulfil Jesus' mandate for mission in the world of the $21^{\text {st }}$ century whereby the pluralism of religion is most vivid, the relativity of ideas is embraced greatly, and where are events of economic, social, political and religious injustices so prevalent? In other words, what does it mean for the African church to do mission work in this age whereby the religions embraced by people and their worship systems are great determinants of their lives, whereby the economic system is controlled by few super powers while the majority starve and mourn?

Moreover, the most striking aspect between "us" as the African church and "them" as members of other religions and cultures, and great nations, is the way people can differentiate themselves and their claims in relation to theirs. People claim to worship God in their African churches; they also claim to worship their gods in their temples and churches. We claim our God to be legitimate and powerful, and so do they. Moreover, the worshippers of the gods, and the economic oppressors, are human beings like them and are their neighbours who live in their vicinity. People attend in the same markets, shops and their children attend in the same schools as their children. We also drive in the same roads and live together in the same streets. What actually is the significant difference between "us" and "them" that obliges their African churches to do mission towards "them"? Are the none-Christians people live with as destitute as they construct them to be? These concerns raise tangible questions in this era of globalization and religious pluralism and might be the sole cause for the African church's lackadaisical situation to fulfil God's mandate stated in the Great Commission (David J. Bosch, 2011).

It might be this time that the African church of the $21^{\text {st }}$ century context, because of her irresponsibility, sees it better to enjoy the benefits of the church owner (God's loving care and mercy) without taking into 
account her obligation to set her foot towards those that suffer from the consequences they do not deserve and send God's message to both sufferers and causers of that suffering. Karl Bath, uttering on Christian vocation points out thus: "to be called means to be given a task (...).The focus of the call is not the enjoyment of personal salvation, but the commission given by the Lord who calls (...) (Walren Scott, 1975, p. 211). In this case, the message of the book of Jonah brings to light the knowledge that the sovereignty of God and God's plans for universal salvation rule out all human endeavours of making the African church egocentric. The message of God is for all; it is for God's people in all situations and times. In order for the message of God to be heard by all people, in all situations, and at all times, there must be a people to proclaim (the preachers). Who will be the preacher of the message of God to people of the 21st century and their globalizing situation if not the witnessing community of believers (the African church)?

\section{Conclusion}

A word of conclusion for this article stresses on the sovereignty of God and the mandate for the African church to advance her mission to people of all ages. The Great Commission does not indicate the end of mission. Rather, it advocates for the continuous work of the African church in various contexts and ages. This article has argued that Jonah's mandate to do mission to Nineveh the great city on Assyrian empire and his refusal to fulfil God's sovereign plan implies the African church's reluctance to work towards the Great Commission in the $21^{\text {st }}$ century context.

The mission of the African church in the $21^{\text {st }}$ century requires the African church to perpetuate the very initial plan of God to incorporate all people, including the economic oppressors and people of other religions, in the salvation. Nineveh, the heathen city was in God's plan despite Jonah's repudiation to preach the message of salvation to her. The globalized world and her pluralistic religious affiliations, economic injustices, and oppression of the weak by powerful nations, are the very context where God's missionary work requires visibility and viability. Christ needs to be preached and re-preached according to the current context. As the work of Jonah was to preach the great deeds of God and leave God's Spirit to work in the hearts of the king and his subordinates, the current context of the African church requires the word to be preached and leave an ample space for the Holy Spirit to work upon those who hear the preached word. This means that a prophetic message is what is urgently needed to address the cultural, religious, economic, and social effects of globalization.

Moreover, the article has found out that mission is not static, focusing only on conversions of the so-conceived "heathens". It is not only the pointing of fingers upon "them" as being the target people for our mission work. De la Torre (2007) argues:

“The 'white man's burden' of Christianizing and civilizing the pagans was a process pregnant with the prejudice and paternalism of racial superiority - a process responsible for cultural, if not physical, genocide. It is not surprising that the voices of the world's marginalized rejected this form of evangelism (p. 123).

What De la Torre suggests is that in this globalized world, a different approach to mission is needed in order to make the gospel available to all kinds of people.

Bevans (2011) shares the same point of view as the one suggested by De la Torre above when he states: "In the global, multicultural, minority-status, poor, vulnerable, ecologically threatened church of the $21^{\text {st }}$ century (...) [mission] is a very different kind of mission than was conceived by Anglicans, Baptists, Marists, and Josephites a century ago" (p. 102). The two scholars above suggest that mission in the $21^{\text {st }}$ century needs to 
be dialogical. It needs to be a way of trying to understand each other and the truths they hold. Bevans (2011) further states this understanding of mission more obviously:

"Mission, in other words, cannot be reduced to one element, particularly to conversion efforts. It needs to include committing oneself to issues of justice, peace, and the integrity of creation; it needs to proceed with cultural and contextual sensitivity; and it needs to proclaim Christian convictions within the context of an honest dialogue with the world's religions” (p. 102).

Therefore, according to Bevan's statement above, absolute truth is not something one religion can claim to have; but it is something relatively negotiated among various religions.

In support to the above point of view, Hearne (1993) also posited thus: "We live in a world in which there are no certain certainties, despite the claims of the religious and secular fundamentalists" (pp. 93-94). According to Hearne's statement, this means that Christianity has its absolute truth that needs to be duly defended and held because it is the truth that God revealed through this religion, and so do other world religions. The existence of uncertain certainties is a clear implication made by the notion of dialogue as a missionary strategy within such kind of context.

The aim of mission as a dialogical encounter is to make the world a better place to live, a place where every inhabitant will say "Thanks God that I am here despite the human weaknesses I might have”. This means that mission as dialogue does not focus on people's differences, but on what brings them together despite their cultural, racial and technological differences. It is being open to one another, especially to criticisms and challenges that enrich. In fact "One enters into mission with a profound openness to the place and to the people in which and among whom one works" (Bevans, 2011, p. 103). In this way, "'Mission means a readiness to look out for, to discover, the seeds of the Word which are already present in every human situation” (Hearne, 1993, p. 95).

Dialogical mission, as observed in this article, challenges the spirit and attitude of Jonah, a spirit that says no to God's mandate and initiatives to bring Nineveh and the world making it a better place for her inhabitants. It challenges the approach that only longs for conversion of other people as if their cultural values and religions are irrelevant. It vehemently emphasizes an approach that requires people "to take off our shoes for the place we are approaching is holy” (Bevans, Stephen B, 2011, p. 103). This is mostly the meaning of the inclusion of Nineveh in God's plan of salvation despite Jonah's repudiation and anger. In this case, the article has argued that the African church's mandate for mission according to the Great Commission in the $21^{\text {st }}$ century does not entail being angry with and polemic to people of other religions and their practices, and neither to the rich nations that find God irrelevant because of what they have while oppressing the poor; rather, it involves bringing Christ to people of those religions and economic statuses in order to convince them about God's power and sovereign will as revealed in the Christian religion. As Hearne (1993) sums up:

"This is the hope of a future world community in which all people have an equal place, in which justice prevails for all, and in which every culture plays its part, not just the oppressive and dehumanizing technology of the day” (p. 97).

\section{References}

Barbara Green. (2005). Jonah’s Journeys. (p. 140). Minnesota: Liturgical Press.

Bevans, Stephen B. (2011). A Theology of Mission for the Church of the $21^{\text {st }}$ Century: Mission as Prophetic Dialogue. Contextual Theology for the $21^{\text {st }}$ Century. Stephen B. Bevans., \& Katalina Tahaafe-Williams, (Eds.), (pp. 102-103). Eugene, Oregon: Wipf and Stock Publishers. 
Brian, Hearne. (1993). New Models of Mission. The Furrow, 44(2), 91, 95, 97.

David J. Bosch. (2011). Transforming Mission: Paradigm Shifts in Theology of Mission. (pp. 57-70). Maryknoll, New York: Orbis Books.

De la Torre. (2007). Liberating Jonah: Forming an Ethics of Reconciliation. Maryknoll, New York: Orbis Books.

Donald Senior., \& Carroll Stuhlnueller. (1983). The Biblical Foundations for Mission. (p. 321). Maryknoll, New York: Orbis Books.

Hugh Martin. (1958). The Prophet Jonah: His Character and Mission to Nineveh. (pp. 344-345). London: The Banner of Truth Trust.

Jesse N.K. Mugambi. (1989). The Biblical Bases for Evangelization: Theological Reflections based on an African Experience. (pp. 5-7). Nairobi: Oxford University Press.

Jooseop Keum. (2011). Mission as an Invitation to the Feast of Life: Re-visioning the Ecumenical Understanding and Practice of Mission in the $21^{\text {st }}$ Century. Contextual Theology for the $21^{\text {st }}$ Century. Stephen B. Bevans., \& Katalina Tahaafe-Williams. (Eds.) (pp. 109-125), Eugene, Oregon: Wipf and Stock Publishers.

Leslie C. Allen. (1976). The Books of Joel, Obadiah, Jonah and Micah. (pp. 203-234). Grand Rapids, Michigan: William B. Eerdmans.

Paulo Isack Akyoo. (1987). Effective Pastoral Leadership in the ELCT with Reference to the Northern Diocese. (pp. 88). Dubuque: Wartburg Theological Seminary.

Robert J. Schreiter. (1997). The New Catholicity: Theology between the Global and the Local. (p. 8). Maryknoll, New York: Orbis Books.

T. Watson Street. (n.d.). On the Growing Edge of the Church. Crossroads in Mission. (p. 25). South Pasadena: William Carey Library.

Walren Scott. (1975). Karl Barth’s Theology of Mission. Missiology: An International Review, 3(2), 211. 